\title{
TARGET-ORIENTED SYNTHESIS OF SOME TERPENOIDS OF MARINE ORIGIN
}

\author{
Nicon Ungur \\ Institutul de Chimie al A.Ș.M. str. Academiei 3, MD-2028, Chișinău, Republic of Moldova \\ E-mail:nicon.ungur@gmail.com,fax:+37322 739775; tel.: + 37322739769.
}

\begin{abstract}
The paper presents an outline of the synthesis of some natural terpenoids of marine origine having diverse carbocyclic skeletons: labdanic, isocopalic, scalaranic, cheilanthanic, drimanic, sacculatanic. Schemes - 6, figures -2 . Bibliographic references -35 .
\end{abstract}

Keywords: marine natural products, terpenoids; glycerol; scalaranes, cheilanthanes, sesterterpenoids, cyclizations, superacids, rearrangements, synthesis.

Terpenoids constitute one of the numerous class of natural products. They represent not only academic interest. Most of them possess biological activity and regulate different vital processess in both vegetal and animal world, including marine and microorganisms [1-3].

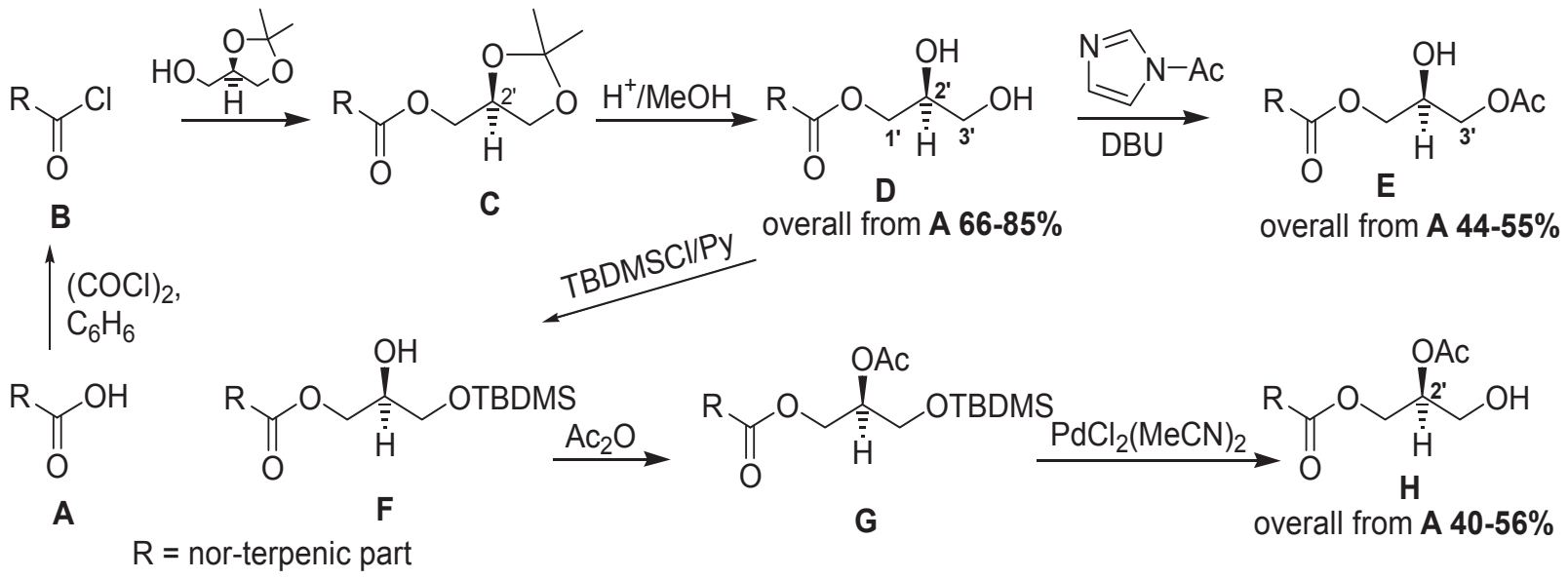

Scheme 1

Terpenoid acylglycerols represent an interesting group of natural bioactive molecules, which could be considered the chemical marker of marine dorid nudibranchs belonging to the related genera Anisodoris, Archidoris, Austrodoris, Doris and Sclerodoris [4-5].

Synthesis of natural bicyclic and tricyclic diterpenoid diacylglycerols has been performed by regioselective coupling of terpenoid acid with glycerol at 1'-sn position. This method may be considered a general approach to obtain optically active acylglycerols. (Scheme 1).

Terpenic acids (1-6) (Figure 1) have been synthesized from commercially available substances: sclareol (7), E,E-farnesol (8), and copalic acid (9) - extracted from commercial “Copaiva Balsam” oil. 

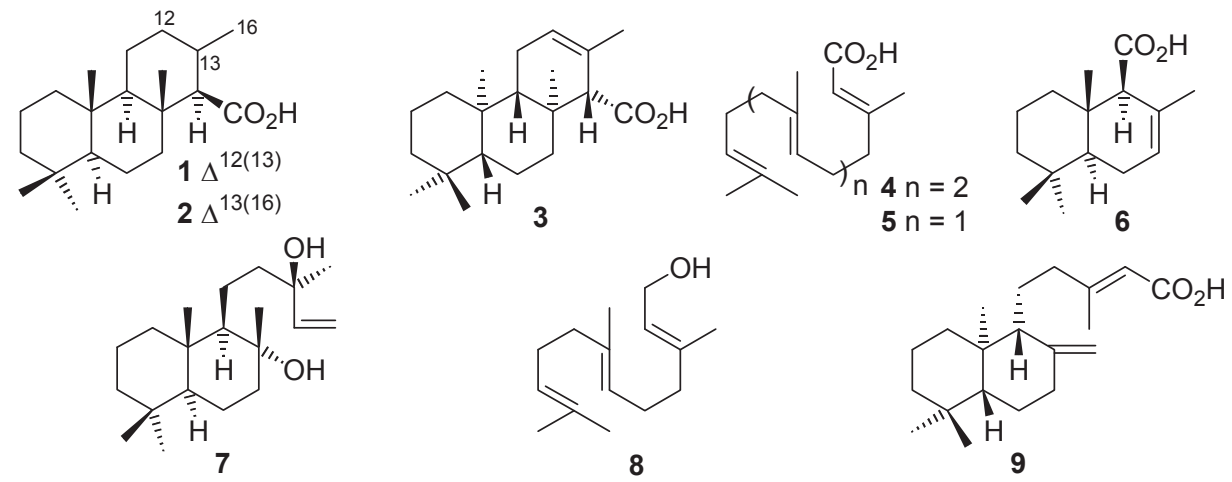

Figure 1

A series of natural di- and sesquiterpenic acylglicerols (10-23) have been synthesized (Figure 2) according to an elaborated procedure [6-11]. It should be mentioned, that diterpenoid acylglycerols are toxic to fish but also activators of protein kinase $\mathrm{C}$ and very active in regenerative test with the fresh water hydrozoan Hydra vulgaris [12].

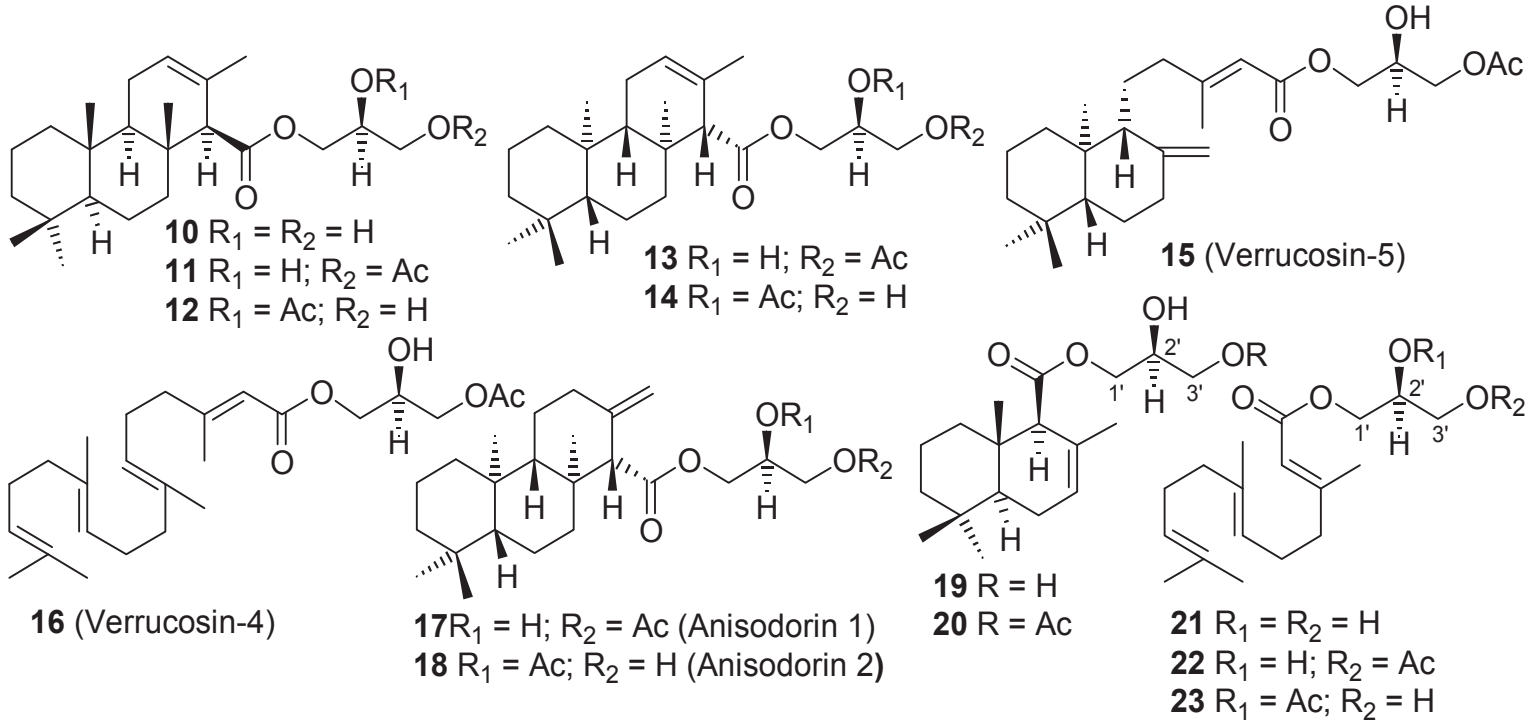

Figure 2

Anisodorid 5 (24) has been isolated from Anisodoris fontaini molluscs [9]. The absolute stereochemistry of tricyclic diterpenoid $\mathbf{2 4}$ was established on comparing with its enantiomer $\mathbf{2 5}$, synthesized by us from the hydroxiacetate 26, a sclareol (7) transformation product (Scheme 2) [14].

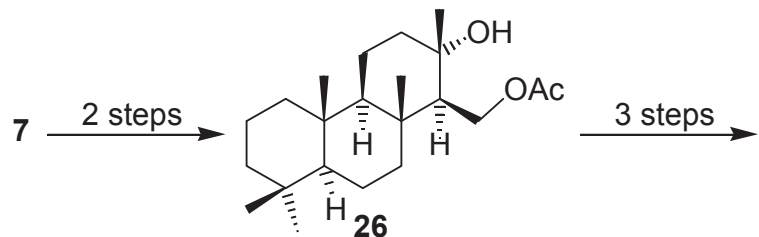

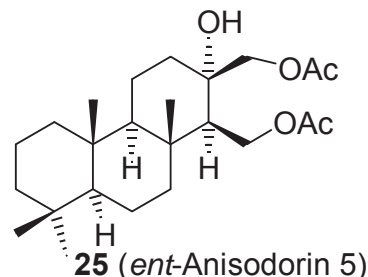

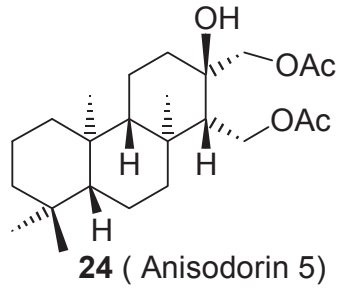

Scheme 2 


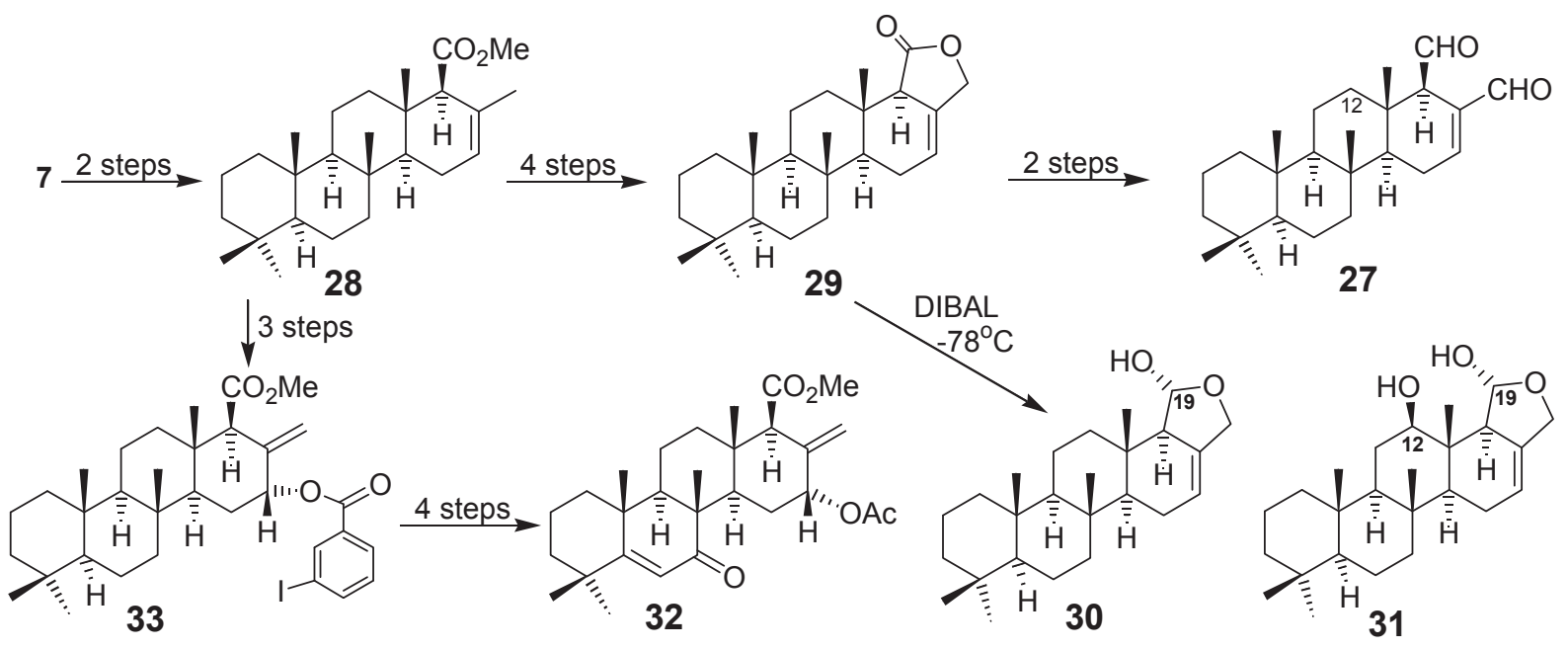

Scheme 3

Scalaranic sesterterpenoids represent a group of natural compounds, isolated basically from marine organisms and which possess diverse biological activity [15]. We have realized the synthesis of natural 12-deacetoxyscalaradial (27), isolated previously from the sponge Cacospongia mollior [16]. The synthesis started from the scalaranic ester 28 via lactone 29 [17].

Lactol 30, obtained on the selective reduction of lactone $\mathbf{2 9}$ has contributed to the elucidation of stereochemistry at $\mathrm{C} 19$ in the natural scalaranic 12-deacetyl-12-epi-deoxoscalarin (31) [18]. The scalaranic ester 28, readily available from sclareol (7), was successfully used for the synthesis of B-ring functionalized scalarane 32. The so called Radical Rely Halogenation of the intermediate $\mathbf{3 3}$ has served for the specific remote functionalization (Scheme 3) [19]. It is noteworthy mentioning that the synthesis of scalaranic sesterterpenoids, including those with advanced functionalization, has been paid a lot of attention by the scientific comunity [20-26].

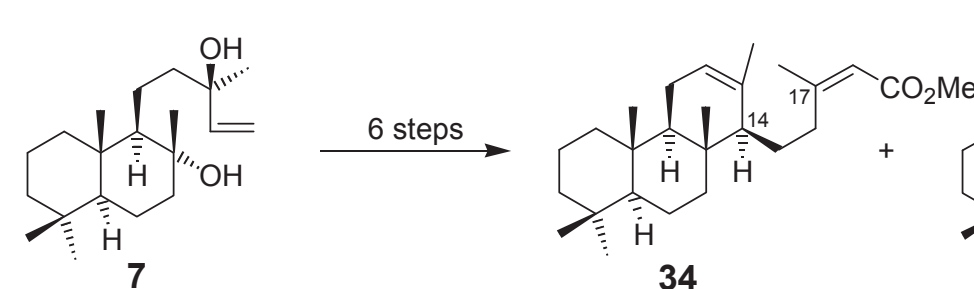

7

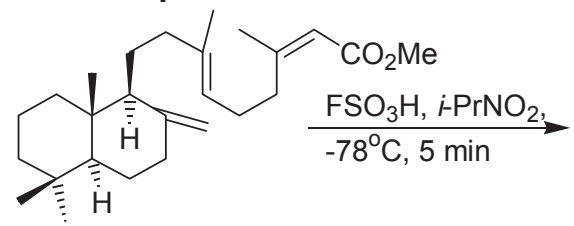

41<smiles>CC(=O)/C=C(/C)CC[C@H]1CC[C@H]2[C@@H](C)CCC[C@]2(C)[C@H]1C</smiles>

$36(60 \%)$

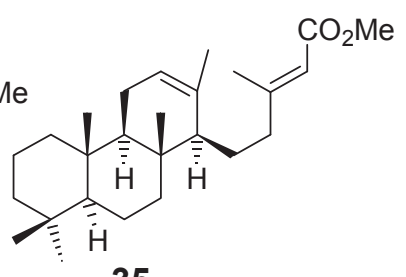

35

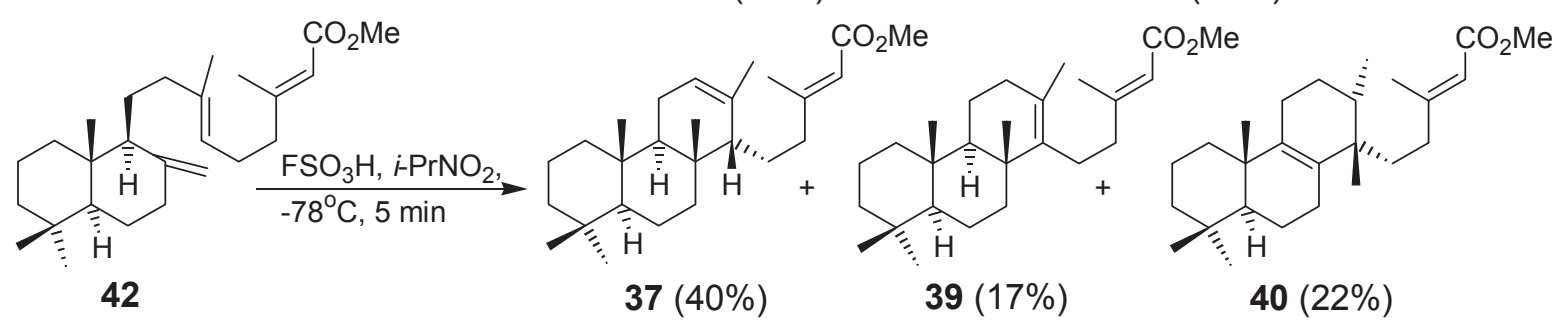

Scheme 4

Natural cheilanthanic sesterterpenoids have been isolated both from marine organisms and plants [27]. They possess a broad spectrum of biological activities and their synthesis represents an actual priority. We have performed a 6-step synthesis of isomeric cheilanthanic esters 34 and 35 [28], starting from sclareol (7). The synthesis of cheilanthanic 
esters 36 and 37, which are C14-epimers of esters 34 and 35, has been performed by superacidic cyclisation of esters $\mathbf{4 1}$ and $\mathbf{4 2}$ (Scheme 4). It is noteworthy mentioning that in addition to esters $\mathbf{3 6}$ and 37, their C-ring double bond isomers $\mathbf{3 8}$ and $\mathbf{3 9}$ have been produced, along with substantial amount of rearranged cheilanthane $\mathbf{4 0}$ [28,29].

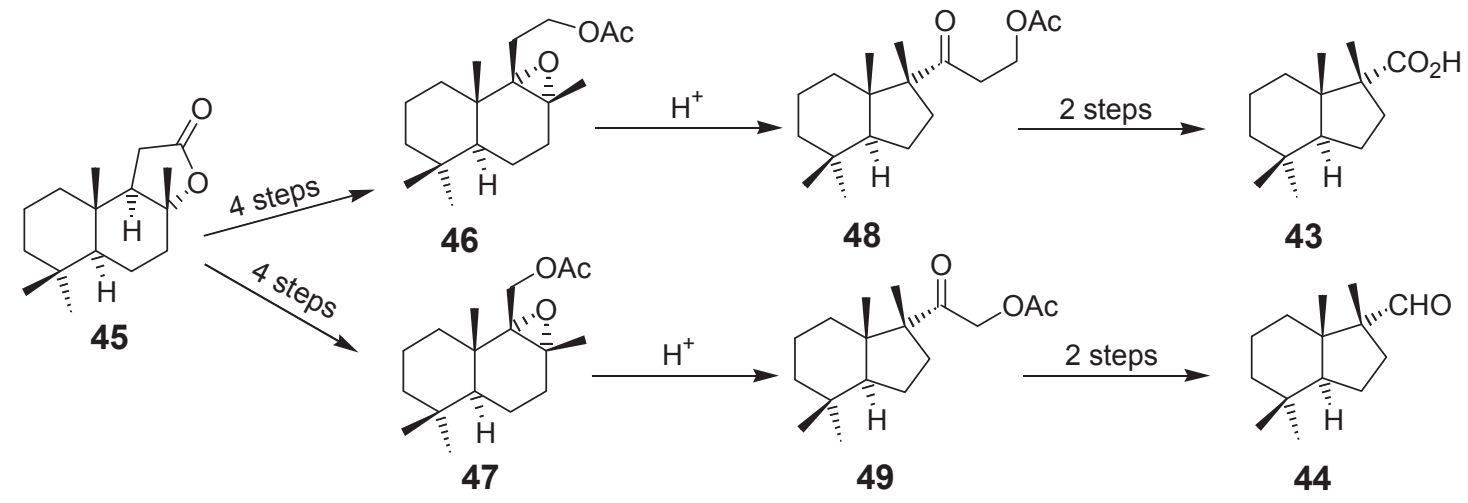

Scheme 5

Austrodoric acid (43) and austrodoral (44) were isolated from the skin extract of Antarctic dorid nudibranch Austrodoris kerguelenensis [30]. We have realized the synthesis of these norsesquiterpenic compounds starting from commercially accessible sclareolide (45) (Scheme 5). Lactone 45 was transformed in 4 steps to epoxides 46 or $\mathbf{4 7}$, which rearranged under acidic conditions to the ketoacetates $\mathbf{4 8}$ and $\mathbf{4 9}$ respectively. These have been converted to austrodoric acid (43) [31] and austrodoral (44) [32] respectively.

Gem-dimethyl prenylated terpenoids have been isolated from natural sources and showed biological activity [33]. We have elaborated a biomimetic procedure for their synthesis, using as a key step the superacidic cyclisation of open chain $\alpha, \omega$-bifunctionalized terpenes. The starting subsrates $\mathbf{5 0}$ and $\mathbf{5 1}$ have been obtained from readily available $E, E$-farnesol (8) and E,E,E-geranyllinalool (52) (Scheme 6). On cyclization of bifunctionalized sesquiterpenoid $\mathbf{5 0}$ a mixture of two monocyclic compounds $\mathbf{5 3}$ and $\mathbf{5 4}$ is obtained, while the diterpenic substrate $\mathbf{5 1}$ led selectively to sacculatanic diterpenoids 55 and 56 [35].

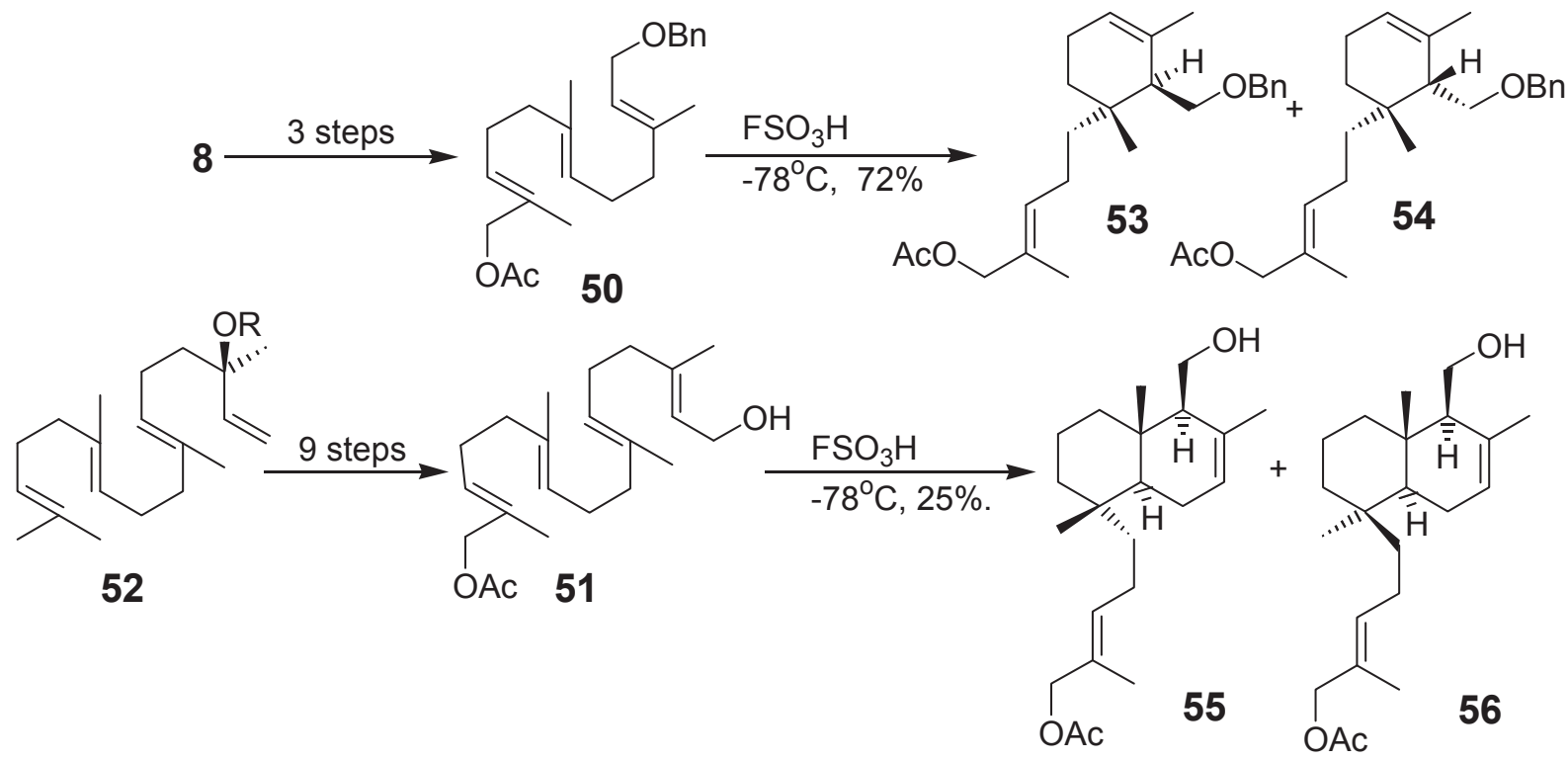

Scheme 6

\section{Conclusions}

Our investigations in the field of the synthesis of terpenoids of marine origin have led to:

- elaboration of a general method for the synthesis of natural terpenic mono- and diacylglicerols, as well as of other polifunctionalized isocopalic diterpenoids;

- synthesis of some natural scalaranic sesterterpenoids and some B-ring functionalized ones; 
- obtaining of stereoisomeric cheilanthanic sesterterpenoids;

- $\quad$ synthesis of natural nor-sesquiterpenoids - austrodoral and austrodoric acid;

- $\quad$ biomimetic synthesis of terpenoids from sacculatane series.

Acknowledments. Academy of Sciences (Moldova) and CNR (Italy) are acknowledged for financial support (bilateral project 11.820.08.01/ItF "Novel approaches for the synthesis of optically active cannabinoids with relevant biological activity and therapeutical potential" 2011-2012).

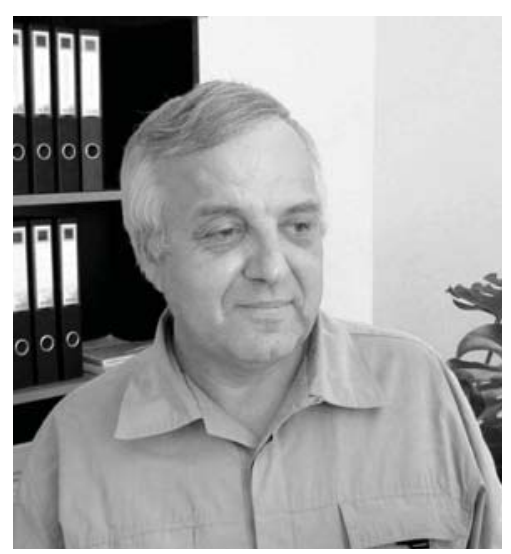

Dr. Sci. Nicon Ungur was born in 1954. He graduated from Moldova State University in 1976 and obtained his Ph.D. degree in 1985 from the A. V. Bogatsky Physico-Chemical Institute of the Ukrainian Academy of Sciences, Odessa under the supervision of Professor P. F. Vlad. In 1994, he finished his Habilitation and obtained a Dr. Sci. degree. He was a postdoctoral fellow with Professor G. Cimino (ICB, Naples, Italy), where he got his training in the synthesis of natural terpenoids. He is the author of more than 90 scientific papers including reviews and ten patent applications. He is currently head of the laboratory of terpenoid chemistry, at the Institute of Chemistry, Moldova Academy of Sciences. His research interests include the synthesis of mono-, sesqui-, di- and sesterterpenoids; the electrophilic, superacidic cyclisation and molecular rearrangements of terpenoids; and the synthesis of natural terpenoids, including the biologically active compounds.

\section{References}

[1]. Frija, L. M. T.; Frade, R. F. M.; Afonso, C. A. M. Chem. Rev., 2011, 111 (), 4418-4452.

[2]. $\quad$ Awen, B. Z. S.; Nozawa, M.; Hagiwara, H. Org. Prep. Proced. Int., 2008, 40 (4), 317-363.

[3]. Jansen, B. J. M.; De Groot, A. Nat. Prod. Rep., 2004, 21 (), 449-477.

[4]. Faulkner, D. J. Ecological Roles of Marine Natural Products; Paul, V. J., Ed.; Comstock Publishing Associates: Ithaca, NY, 1992, pp 119-163.

[5]. Cimino, G.; Fontana, A.; Gavagnin, M. Curr. Org. Chem., 1999, 3, 327-372.

[6]. Ungur, N.; Gavagnin, M.; Cimino, G. Tetrahedron Lett., 1996, 37 (20), 3549-3552.

[7]. Fontana, A.; Ungur, N.; Gavagnin, M.; Salierno, C.; Cimino, G. Tetrahedron Lett., 1997, 38 (23), $4145-4148$.

[8]. Gavagnin, M.; Ungur, N.; Castelluccio, F.; Cimino, G. Tetrahedron, 1997, 53 (4), 1491-1504.

[9]. Gavagnin, M.; Ungur, N.; Castelluccio, F.; Munian, C.; Cimino, G. J. Nat. Prod., 1999, 62 (2), $269-274$.

[10]. Ungur, N.; Gavagnin, M.; Fontana, A.; Cimino, G. Tetrahedron Asymm., 1999, 10, (7), 1263-1273.

[11]. Ungur, N.; Gavagnin, M.; Fontana, A.; Cimino, G. Tetrahedron, 2000, 56 (16), 2503-2512.

[12]. De Petrocellis, L.; Di Marzo, V.; Arca, B.; Gavagnin, M.; Minei, R.; Cimino, G. Comp. Biochem. Physiol., 1991, 100C, 603-607.

[13]. Ungur, N.; Gavagnin, M.; Mollo, E.; Cimino, G. Tetrahedron Asymm., 1999, 10 (9) 1635-1636.

[14]. Vlad, P. F.; Ungur, N. D.; Barba, A. N.; Tatarova, L. E.; Gatilov, Y. V.; Korchagina, D. V.; Bagrianskaya, I. Y.; Gatilova, V. P.; Shmidt, E. N.; Barkhash, V. A. Zh. Org. Khim. 1986, 22, 2519-2533. [J. Org. Chem., U.S.S.R. 1986, 22, 2261-2273 (Engl. Transl.)].

[15]. González, M. A. Scalarane Sesterterpenoids. Curr. Bioact. Compd., 2010, 6 (3), 178-206.

[16]. De Rosa, S.; Puliti, R.; Crispino, A. et al. J. Nat. Prod., 1994, 57 (2), 256-262.

[17]. Ungur, N.; Gavagnin, M.; Cimino, G. Nat. Prod. Lett., 1996, 8 (2), 275-280.

[18]. Fontana, A.; Cavaliere, P.; Ungur, N.; Cimino, G.; D’Sousa, L.; Parameswaram, P. S. J. Nat. Prod., 1999, 62 (10), 1367-1370.

[19]. Kulcițki, V.; Ungur, N.; Gavagnin, M.; Castelluccio, F.; Cimino, G Tetrahedron, 2007, 63 (32), $7617-7623$.

[20]. Ungur, N.; Kulciţki, V. Phytochemistry Review, 2004, 3, (3), 401-415.

[21]. Ungur, N.; Kulciţki, V. In: Recent Res. Dev. Org. Chem. 2003, 7, 241-258.

[22]. Meng, X.-J.; Liu, Y.; Fan, W.-Y.; Hu, B.; Du, W.; Deng, W.-P. Tetrahedron Lett., 2009, 50 (35), $4983-4985$.

[23]. Fan, W.-Y.; Wang, Z.-L.; Zhang, Z.-G.; Li, H.-C.; Deng, W.-P. Tetrahedron, 2011, 67 (31), 5596-5603.

[24]. Wang, Z.-L.; Zhang, Z.-G.; Li, H.-C.; Deng, W.-P. Tetrahedron, 2011, 67 (36), 6939-6943.

[25]. Chen, X.-B.; Yuan, Q.-J.; Wang, J.; Hua, S.-K.; Ren, J.; Zeng, B.-B. J. Org. Chem., 2011, 76 (17), $7216-7221$. 
[26]. Fan, W.-Y.; Wang, Z.-L.; Li, H.-C.; Fossey, J. S.; Deng, W.-P. Chem. Commun., 2011, 47 (10), $2961-2963$.

[27]. Ungur, N.; Kulcitki, V. Tetrahedron, 2009, 65 (19), 3815-3828.

[28]. Ungur, N.; Kulcitki, V.; Gavagnin, M.; Castelluccio, F.; Cimino, G. Synthesis, 2006, (14), 2385-2391.

[29]. Ungur, N.; Kulcitki, V.; Gavagnin, M.; Castelluccio, F.; Vlad, P. F.; Cimino, G. Tetrahedron, 2002, 58 (51), 10159-10165.

[30]. Gavagnin, M.; Carbone, M.; Mollo, E.; Cimino, G. Tetrahedron Lett., 2003, 44, 1495-1498.

[31]. Kulcitki, V.; Ungur, N.; Gavagnin, M.; Carbone, M.; Cimino, G. Tetrahedron Asymm., 2004, 15 (3), $423-428$.

[32]. Kulciţki, V.; Ungur, N.; Gavagnin, M.; Carbone, M.; Cimino, G. Eur. J. Org. Chem., 2005, (9), 1816-1822.

[33]. Asakawa, Y. Phytochemistry, 2004, 65 (6), 623-669.

[34]. Kulcitki, V.; Ungur, N.; Vlad, P. F.; Gavagnin, M.; Castelluccio, F.; Cimino, G. Synthesis, 2000, (3), 407-410.

[35]. Grinco, M.; Kulcițki, V.; Ungur, N.; Vlad, P. F.; Gavagnin, M.; Castelluccio, F.; Cimino, G. Helv. Chim. Acta 2008, 91 (2), 249-258. 